\author{
Гриб В. I., \\ кандидат фбілософбських наук, \\ доцент кафедри правових наук та фбілософбії \\ Вінницького державного педагогічного університету \\ ілені Михайла Коцюбинського
}

\author{
Конотопенко О. П., \\ кандидат фбілособбських наук, \\ доцент кафедри правових наук та фбілософбї \\ Вінницького державного педагогічного університету \\ імені Михайла Коцюбинського
}

\title{
ЄДНІСТЬ ФІЛОСОФІї ТА КУЛЬТУРИ У ФОРМУВАННІ ЦІЛІСНОСТІ СУЧАСНОЇ ОСОБИСТОСТІ
}

\begin{abstract}
Анотація. У статті розглядаються світоглядні та моральні основи буттєвої самореалізації сучасної людини, яка можлива лише на основі активної соціокультурної самоідентифікації. Актуальність дослідження зумовлена реаліями сьогодення, проблемами діяльності, причинами та факторами, які формують сучасну людину. Реальність буття висуває перед людиною нові вимоги щодо світоглядно-ціннісного формування іiї особистісної та соціальної сутності. Головна мета статті - концептуалізація та систематизація здобутків філософії та їхнього значення для формування сучасної людини. В основі дослідження - виявлення принципу формування сучасного типу людини на основі толерантності, чесності та людяності. Наукова новизна дослідження полягає в комплексному аналізі формування світогляду, філософії, моралі сучасної людини, визначенні основних аспектів впливу філософії на ії життя. Філософія, світогляд і мораль є складовими частинами загальнокультурного простору сучасного соціального розвитку суспільства. Проаналізовано основні напрями розвитку філософії та розглянуто сфери суспільного життя, у яких наявна філософія, як-от: інтелектуальна культура й ерудиція людини, внутрішній світ людини, освіта, наука. Зазначено, що в цих сферах роль і значення філософії трактуються суперечливо. У результаті проведення дослідження було з'ясовано, що філософія не лише використовує досягнення наук, а й сама впливає на їх розвиток. Її вплив проявляється через філософський світогляд дослідників і методологію організації та проведення досліджень. Отже, людина є творцем, джерелом інноваційної активності, носієм духовно-вольового прагнення до перетворення навколишньої дійсності та самої себе, до самореалізації своїх внутрішніх потреб і прагнень, для яких філософія є вкрай необхідною.

Застосовано системний та комплексний підходи як методи дослідження визначеної проблеми. Перспективи дослідження - 3'ясувати, як філософія має допомогти сучасній людині самовизначитися.
\end{abstract}

Ключові слова: сучасна людина, соціокультурна самоідентифікація, філософія, освіта.

Постановка проблеми. Актуальність дослідження зумовлена реаліями сьогодення, проблемами діяльності, причинами та факторами, які формують сучасну людину. Реальність буття висуває перед людиною нові вимоги щодо світоглядно-ціннісного формування іiі особистісної та соціальної сутності. Надшвидка динамічність знаково-інформаційної цивілізації змушує людину включати у структуру власної феноменологічності такий елемент, як підприємливість, без якого неможливе набуття соціокультурної суб'єктності в надскладному інформаційному світі.

Аналіз останніх досліджень і публікацій. Результати наукового пошуку дозволяють зробити висновок про те, що проблема формування сучасної людини була предметом досліджень багатьох видатних вітчизняних і закордонних учених: В. Андрущенка, В. Воронкової, А. Абрамової та ін. $[1 ; 2 ; 6 ; 7 ; 8 ; 10]$.

Мета статті - обгрунтування цілісної соціально-філософської концепції формування людини в сучасних соціокультурних умовах.

Новизна дослідження полягає у визначенні основних аспектів впливу філософії на життя сучасного суспільства й аналізі iï основних напрямів.

Виклад основного матеріалу дослідження. Сучасність у філософії має свій внутрішній масштаб. За звичкою, початком сучасного етапу вважають кінець ХІХ ст., коли виникли нові форми філософствування, що стали панівними в Європі XX ст., основні ідеї яких розробляються і сьогодні. ХХ ст. - особливий етап у розвитку сучасного суспільства. Воно вирізняється конфліктністю, суперечливістю, інтенсифікацією соціальних процесів, прискоренням темпів соціальних змін. Зрештою, це час зародження глобальних проблем. Усе це не могло не позначитися на характері тих питань, які висували філософи. Філософська парадигма XX ст. виступає як планетарне явище й могутня поліфонія етносоціальних світоглядних ментальностей.

Сучасна філософія є часткою світової культури і має статус вселюдської цінності. Ї̈̈ вивчення дає ключ до розуміння багатьох процесів, що відбувались і відбуваються в духовному житті західного суспільства, інтенсивного діалогу, за яким орієнтується сьогодні Україна.

Філософію, яка існувала до середини XIX ст., називають класичною. Це був значний крок у становленні теоретичної думки порівняно з усім попереднім філософським розвитком. Характерна ознака цієї філософії - безмежна віра в розум. 
Філософам-класикам властивий пізнавальний оптимізм, упевненість у тому, що раціональне пізнання, зокрема наука, є тією силою, яка згодом дасть змогу вирішити всі проблеми, які стоять перед людством. Особливістю класичної філософії є також те, що, розглядаючи людину й історію, вона сконцентрувала свою увагу навколо проблеми свободи й інших гуманістичних цінностей і стверджувала необхідність раціонального пізнання загальнолюдських моральних принципів та ідеалів.

Філософія ХX ст. (некласична) формувалася насамперед як антитеза класичній, як нове філософське мислення. Вона характеризується наявністю різноманітних шкіл. Найбільш відомі такі: герменевтика, екзистенціалізм, неопозитивізм, неофрейдизм, неотомізм, персоналізм, прагматизм, структуралізм, феноменологія, філософська антропологія, марксизм та ін. Проте це аж ніяк не означає іiї фрагментації та деградації цілісності. Навпаки, сучасна філософія набула «загальнолюдського», «планетарного» характеру. Річ у тім, що XX ст. - це час становлення нового рівня цілісності людства, яке починає активно визначати себе як суб'єкт загальнолюдської практики. За цих умов філософія вперше за всю свою історію стає реально «світовою філософією» - iї провідні школи набувають статусу світових тенденцій планетарності філософської думки.

Сучасна філософія зазвичай відмовляється від раціоналізму: стає на позиції ірраціоналізму. Ірраціоналізм - це система філософських вчень, які обстоюють обмеженість раціонального пізнання, протиставляють йому інтуїцію, віру, інстинкт як основні види пізнання. Як філософська течія ірраціоналізм сформувався у XIX ст. У XX ст. цей стиль філософствування починає домінувати в західній філософії; «філософію мислення» замінює «філософія життя».

Більшість сучасних філософських систем мають антропологічний характер. Вони поєднуються загальною особливістю: наявністю спільного підходу до визначення головної філософської проблеми, а саме проблеми людини. Антропологізм виявляється у спробах визначати основи і сфери людської особистості та суб'єктивності, розглядати людину як «міру всіх речей», iз неї та завдяки їй намагатися зрозуміти як їі саму, так і навколишнє середовище (природу, суспільство), а також культуру.

У сучасній філософії спостерігається суперечливе ставлення до науки (сцієнтизм і антисцієнтизм). 3 одного боку, наука - це універсальне «всезнання», що містить відповіді на всі питання і дає людині абсолютну гарантію успішності іiі безпосередніх дій у будь-яких життєвих ситуаціях, а з іншого вона $є$ загрозою існування людства.

За сучасної епохи набула подальшого розвитку релігійна філософія. Спроби релігійного осмислення дійсності відрізняються від наукових методів, мають свою специфіку. Однак i в руслі релігійної думки народжувались та народжуються видатні філософські вчення, що значно впливають на культуру людства.

У ХХ ст. більшість філософських шкіл і течій протистояли філософії марксизму. Це визначалося тим, що на довгі роки марксизм стає наріжним каменем ідеології та політики суспільства, яке намагалося на практиці реалізувати комуністичні ідеї. У прагненні довести неспроможність принципів марксизму більшість представників філософських течій віддали данину їх критиці. Довгі роки розвиток філософії здійснювався у сфері ідеологічного протиборства. Замість того, щоб вирішувати суто філософські проблеми, сторони відшукували вади та слабкі місця у філософських концепціях одна одної. На цьому тлі посилювалися намагання побудови філософських систем, які прагнули звільнення від впливу ідеології, природознавства і навіть науки.

Наприклад, представники сучасного філософського постмодернізму давно вже оголосили про «смерть філософії», поставивши ii в один ряд із лавиною подібних смертей «смерть людини», «смерть суб'єкта», «смерть культури» тощо [2, с. 11-123]. Деякі епатажні автори, які претендують на те, щоб представляти філософський авангард, кажуть про принципове безпліддя сучасної філософської думки, про іії віддаленість від людини і від реальних проблем суспільства [3, с. 7-12]. Означені явища, на перший погляд, суперечать певним фактам життя. Наприклад, в Україні новими законодавчими та міністерськими рішеннями для науковців будь-яких галузей знань вводиться єдиний науковий ступінь «доктор філософії), а керівники освіти запевняють громадськість у тому, що філософія залишиться на почесному місці в освітніх програмах, хоча водночас іiі все ж усувають із певних видів освітньої діяльності, а самі освітні програми з філософії зводять до такого мінімуму, коли філософська освіта майже втрачає сенс.

Філософія (метафізика) деяким вільним польотом уяви ніби позначає певне предметне поле, на якому пізніше працюють культуротворення та наука. Саме тому філософським (метафізичним) твердженням висувається вимога: «Те, що виявляється на практиці, повинно лежати в межах метафізичного опису. Тоді, коли опису не вдається включити практику, метафізика постає неадекватною та вимагає перегляду» [4, с. 527]. Отже, тоді, коли філософські твердження не мають можливості врахувати «практику», тобто якісь фактичні реальності, вони постають такими, що не відповідають вимогам науки і повинні бути усунутими.

Модернізація й реалізація нової моделі педагогічної освіти має враховувати сутність категорії некласичності формування людини, зваженого співвідношення класичної і сучасної педагогіки та філософії [6, с. 14].

У сучасних навчальних програмах вищої освіти лише до 40\% матеріалу пов' язано з аудиторною роботою, тобто з такою, що передбачає прямий контакт досвідченого науковця-педагога зі студентами. Усе ширше запроваджується система дистанційного навчання та навчання в режимі «онлайн». Половина студентів, що вивчають філософські курси, вважають обтяжливим для себе ознайомлюватись з історією філософії. Не лише студенти, а й представники інших наукових напрямів не розуміють фундаментальної особливості історико-філософського знання: якщо у певних конкретних науках та сферах діяльності справді варто відкинути те, що себе не виправдало або виявилось помилковим, то історія філософії збирає історичний досвід людського життєвого самоствердження, а в такому досвіді немає непотрібного [5, с. 9-12]. Відкидати тут минуле - це все одно, що викидати із свого життя, наприклад, дитинство або юність. Але в підсумку філософські курси, зокрема в Україні, стискають до таких обсягів, що вони просто втрачають сенс, оскільки за 7-10 семінарських занять зі студентами малоймовірно, що хтось зможе прищепити їм інтерес до самостійного та виправданого розгортання думки навколо життєво значущих проблем.

Таке деградоване становище філософського пізнання сприяє стадії, у якій філософія хоче бути наукою і потрапляє в рабську залежність від науки $[9$, с. 5]. 
Проте життя не стоїть на місці, «усе тече, усе розвивається», і проблеми людини дістали своє подальше вивчення, ці проблеми $€$ ще дискусійними і не прийняті всіма вченими [7, с. 277]. Кожна людина - це маленький особистий всесвіт. Ми повинні докласти всіх зусиль, щоби допомогти тим, хто страждає від несправедливості. Для мудрого відкриті всі країни, бо домівка видатної душі - весь світ [10, с. 209].

У глибині віків зароджувалась дивовижна властивість людини сприймати і відтворювати образи навколишнього світу $[8$, c. 10]. Людина володіє властивостями, які можна поступово відкрити у процесі прогресивного розвитку, використовуючи математику і моделі фізики, хімії, мікробіології [1, с. 70].

Сьогодні абсолютна більшість філософських шкіл дотримуються принципу єдності світу, який розуміється не як якісна подоба, а як єдина субстанція, здатна набувати найрізноманітніших форм; водночас серед останніх найбільш протиставленими є матеріальні й ідеальні.

Існуючі у світі відносини дуже різноманітні. Це можуть бути відносини рівності та нерівності, субординації та координації, частини і цілого й ін. Однак серед усіх видів найбільш універсальний характер має відношення залежності, бо все у світі залежить одне від одного. Звичайно, це варто розуміти не у прямому сенсі, хоча в історії існувала думка, що ми не можемо зрушити навіть пальцем, не потурбувавши всієї світобудови. Реальна взаємодія має об'єктивний, універсальний i активний характер, адже навіть властивості об'єкта можуть проявитися і бути пізнаними лише у взаємодії з іншими об'єктами. Наприклад, розкрити, пізнати соціальну сутність людини можна в її діяльності, взаємодії з іншими людьми. Навіть більше, взаємодія незбіжних тенденцій у самому об'єкті, яка виступає як суперечність, $€$ найголовнішим джерелом і причиною його саморуху та розвитку.

Висновки. У результаті проведення дослідження було з'ясовано, що філософія не лише використовує досягнення наук, а й сама впливає на їх розвиток, причому як позитивний, так і негативний. Ї̈ї вплив проявляеться через філософський світогляд дослідників і методологію організації та проведення досліджень. Але багато людей уважають обтяжливим для себе ознайомлюватись 3 історією філософії. Представники багатьох наукових напрямів не розуміють фундаментальної особливості історико-філософського знання: якщо в деяких конкретних науках і сферах діяльності справді варто відкинути те, що себе не виправдало або виявилось помилковим, то історія філософії збирає історичний досвід людського життєвого самоствердження, а в такому досвіді немає непотрібного. Отже, людина $€$ творцем, джерелом інноваційної активності, носієм духовно-вольового прагнення до перетворення навколишньої дійсності та самої себе, до самореалізації своїх внутрішніх потреб і прагнень, для яких філософія $€$ вкрай необхідною.

\section{Лimepamypa:}

1. Фейерабенд Пауль. Наука в свободном обществе. Пер. с англ. А. Никифорова. Москва : А.С.Т., 2010. 378 с.

2. Кутырев В. Смерть человека в философии постмодернизма. Спектр антропологических учений. Вып. 2. / Рос. акад. наук, Ин-т философии ; отв. ред. П.Гуревич. Москва : ИФРАН, 2008. C. $111-123$.
3. Гиренок Ф. Удовольствие мыслить иначе. Москва : Академический проект ; Фонд «Мир», 2010. 235 с.

4. Уайтхед А. Избранные работы по философии / сост., пер. с англ. И. Карсавин ; общ. ред. и вступ. ст. М. Киселя. Москва :Прогресс, 1990. $718 \mathrm{c}$

5. Семенов Н. Философские традиции Востока. Москва : ЕГУ, 2004. $304 \mathrm{c}$.

6. Андрущенко В., Бондар В. Модернізація педагогічної освіти відповідно до викликів XXI століття. Науковий вісник Миколаївського державного університету імені В.О. Сухомлинського. Серія «Педагогічні науки». 2010. Вип. 1.28. С. 12-20.

7. Воронкова В. Людина є не тільки мірою всіх речей, а також і їі творцем. Філософські діалоги. 2010. Вип. 4. Ч. 1 : Філософсько-антропологічні читання: творча спадщина В.І. Шинкарука та сьогодення. Київ, 2010. С. 276-281.

8. Абрамова 3. Древнейший образ человека. Каталог по материалам палеолитического искусства Европы. Санкт-Петербург : Петербургское востоковедение, 2010. 304 с.

9. Бердяев Н. О назначении человека. Париж : Современные записки, $1931.320 \mathrm{c}$.

10. Поппер Карл. Відкрите суспільство та його вороги. Т. І : У полоні Платонових чарів. Пер. 3 англ. Олександр Коваленко. Київ : Основи, 1994. 444 c.

Gryb V., Konotopenko A. The unity of philosophy and culture in shaping the integrity of the modern personality

Summary. The article considers the worldview and moral foundations of the everyday self-realization of the modern man, which is possible only on the basis of active socio-cultural selfidentification. The relevance of the study is caused by the realities of the present, the problems of activity, causes and factors that shape the modern man. The reality of being poses new challenges for a person regarding the worldview and value formation of his or her personal and social essence. The main purpose of the article is to conceptualize and systematize the achievements of philosophy and their importance for the formation of modern man. The basis of the research is the identification of the principle of formation of the modern type of person on the basis of tolerance, honesty and humanity. Scientific novelty of the study is a comprehensive study of the formation of worldview, philosophy, morality of modern man, identifying the main aspects of the impact of philosophy on its life. Philosophy, outlook and morality are at the same time components of the cultural space of modern social development of society. The basic directions of the development of philosophy are analyzed and the spheres of public life in which philosophy is present are considered: intellectual culture and erudition of man, the inner world of man, education, science. It is stated that in these spheres the role and meaning of philosophy are treated inconsistently. As a result of the study, it was found that philosophy not only uses the achievements of the sciences, but also influences their development, both positive and negative. Its impact is manifested through the philosophical worldview of researchers and the methodology of organizing and conducting research. Therefore, man is the creator, the source of innovative activity, the bearer of a spiritual-willed desire to transform the surrounding reality and himself, to self-fulfillment of his inner needs and aspirations for which philosophy is essential.

A systematic and comprehensive approach is applied as a method of researching a particular problem. Research perspectives: how philosophy should help the modern man to define himself.

Key words: modern man, socio-cultural self-identification, philosophy, education. 